\title{
Genetic Improvement of Local Cattle Breeds in West Africa: A Review of Breeding Programs
}

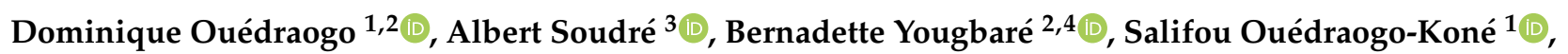 \\ Bienvenue Zoma-Traoré 1,2 (D), Negar Khayatzadeh ${ }^{2}$, Amadou Traoré ${ }^{4}$, Moumouni Sanou ${ }^{4}$, Gábor Mészáros ${ }^{2}(\mathbb{D}$, \\ Pamela Anna Burger ${ }^{5}\left(\mathbb{D}\right.$, Okeyo Ally Mwai ${ }^{6}$, Maria Wurzinger ${ }^{2, *}$ and Johann Sölkner ${ }^{2}(\mathbb{D})$
}

1 Institut du Développement Rural (IDR), Université Nazi Boni (UNB), BP 1091 Bobo-Dioulasso, Burkina Faso; ouedom@gmail.com (D.O.); salifoustallion@gmail.com (S.O.-K.); bienvenidozoma@gmail.com (B.Z.-T.)

2 Division of Livestock Sciences, Department of Sustainable Agricultural System, University of Natural Resources and Life Sciences, Vienna, Gregor-Mendel Street 33, A-1180 Vienna, Austria; yougbernadette@hotmail.fr (B.Y.); kh.negar@gmail.com (N.K.); gabor.meszaros@boku.ac.at (G.M.); johann.soelkner@boku.ac.at (J.S.)

3 Unité de Formation et de Recherche en Sciences et Technologies (UFR/ST), Université Norbert Zongo, BP 376 Koudougou, Burkina Faso; asoudre@gmail.com

4 Institut de l'Environnement et de Recherches Agricoles (INERA), BP 8645 Ouagadougou, Burkina Faso; traore_pa@yahoo.fr (A.T.); lemoune89@gmail.com (M.S.)

5 Research Institute of Wildlife Ecology, Department of Interdisciplinary Life Sciences, University of Veterinary Medicine Vienna, Savoyenstrasse 1,1160 Vienna, Austria; pamela.burger@vetmeduni.ac.at

6 International Livestock Research Institute (ILRI), PO Box 30709, Nairobi 00100, Kenya; O.MWAI@cgiar.org

* Correspondence: maria.wurzinger@boku.ac.at; Tel.: +43-1-47654-93220

\section{check for} updates

Citation: Ouédraogo, D.; Soudré, A.; Yougbaré, B.; Ouédraogo-Koné, S.; Zoma-Traoré, B.; Khayatzadeh, N.; Traoré, A.; Sanou, M.; Mészáros, G.; Burger, P.A.; et al. Genetic Improvement of Local Cattle Breeds in West Africa: A Review of Breeding Programs. Sustainability 2021, 13, 2125. https://doi.org/10.3390/ su13042125

Academic Editor: Roswitha Baumung Received: 7 December 2020

Accepted: 2 February 2021

Published: 17 February 2021

Publisher's Note: MDPI stays neutral with regard to jurisdictional claims in published maps and institutional affiliations.

Copyright: (c) 2021 by the authors. Licensee MDPI, Basel, Switzerland. This article is an open access article distributed under the terms and conditions of the Creative Commons Attribution (CC BY) license (https:// creativecommons.org/licenses/by/ $4.0 /)$.
Abstract: Cattle are one of the most important livestock species in West Africa, providing multiple services to farmers and contributing to national economies. Various breeding strategies have been implemented to enhance their productivity and have improved farmer livelihoods. This review describes cattle breeding experiences across West Africa, spanning the N'Dama breed in Mali, Senegal, and The Gambia to the breeds Azawak Zebu, Fulani Zebu, and taurine Baoulé in Burkina Faso. The main objectives of most breeding programs have been to optimize meat and milk performance of taurine and Zebu cattle as well as trypanotolerance of taurine cattle. In some cases, "closed nucleus" schemes have proven limited and so have evolved into "open nucleus" schemes. Recent communitybased breeding programs have shown promise. The major challenges of breeding programs remain defining realistic breeding objectives and securing the involvement of stakeholders. All the strategies reviewed here have been funded externally within development or research projects that are often too short to yield tangible genetic improvement, and whether they will continue beyond those projects is uncertain. This review highlights the need for continuing government support to ensure the sustainability of local cattle breeding programs.

Keywords: breeding strategies; cattle; local breeds; West Africa

\section{Introduction}

Approximately 300 million heads of cattle are reared in Africa, representing about one fifth of the world's cattle population [1]. In 2017, West Africa alone was home to approximately 74.3 million heads of cattle [2]. Cattle play major social, economic and cultural roles on the continent. They represent a major source of protein (milk and meat) as well as fertilizer and fuel (manure), and they provide draft power for crop farming [3]. Cattle production contributes substantially to African farmers' livelihoods.

Sub-Saharan Africa is home to a large population of indigenous cattle [4], which consist of 150 indigenous breeds supplemented by another 30 introduced exotic and commercial composites [5,6]. In West Africa, 63 local and 23 exotic cattle breeds have been reported [7]. Indigenous breeds, which have long adapted to local environmental 
conditions, are a unique reservoir of genetic resources for the continuous improvement of livestock productivity in Africa and elsewhere [8]. However, most of these breeds show low productivity, which may reflect a lack of exploitation of their genetic potential as well as inadequate nutrition, health services and management [9]. As a result, the production of cattle-derived goods such as milk is grossly insufficient to meet growing demand in various countries, necessitating the import of dairy products.

To improve cattle productivity in West Africa, diverse breeding strategies and policies have been implemented. Like several other developing countries, West African nations have mostly adopted centralized breeding schemes entirely managed by governments with minimal, if any, participation of farmers $[10,11]$. However, few cattle breeding programs in Sub-Saharan Africa have been successful [4]. Previous studies investigated cattle breeding programs implemented in the area, with trypanotolerant N'Dama cattle in Senegal, Mali, and The Gambia [12-20]. Other breeding schemes involving those and other breeds have also been implemented but analyzed in less depth [21,22]. This highlights the need for a comprehensive review of all major breeding programs in West Africa.

To address this gap, the current review consists of three parts. First, it provides an overview of cattle breeds, traits and production systems in the region. Second, it describes in detail six historical and ongoing breeding programs with local cattle breeds, based on scientific publications and unpublished project reports (see Supplementary Materials). To supplement written documents, we conducted informal discussions via email with government technicians in the Ministry of Livestock Resources of Burkina Faso, as well as with extension workers and former employees of some projects. For each breeding program, the review aims to provide context, breeding objectives, breeding schemes applied, and genetic progress achieved. In the case of N'Dama genetic improvement programs in Senegal and Mali (Cases 1 and 2), the description provided here is largely a translation from French publications [15,17].

\section{Review of Cattle Breeds and Genetic Improvement Programs}

\subsection{Cattle Breeds, Traits, and Production Systems in West Africa}

The origin, characteristics, and distribution of African cattle are well documented [1,4, $5,23,24]$. Breeds can be subdivided into the humped Bos indicus, the humpless Bos taurus and the following three combinations: Sanga, which is a stable cross of Bos indicus $\times$ Bos taurus; Zenga, a stable cross of Sanga $\times B$. indicus; and recently derived composite lines, including crosses with exotic temperate breeds [8]. Cattle distribution in Africa depends primarily on socio-economic and environmental factors, such as use of animals for pulling/towing, religious and cultural preferences, availability of feed, pressure from disease and parasites, and ecology [25].

Most cattle production in West Africa occurs in the Sahel, which serves as a geographic and ecoclimatic "bridge" between the Sahara and southern savannas. This area represents a unique geo-climatic territory including very different ecological areas within a few hundred kilometers [26]. Historically, 13 Zebu breeds have inhabited the dry savanna zone and Sahelian belt, while 11 taurine breeds (Longhorn N'Dama, Kuri and Shorthorn breeds) have been widely distributed across the moist savanna and sub-humid coastal forest belt $[5,8]$. However, this distribution has been changing as frequent droughts in the Sahel have driven pastoralists to migrate with their Zebu to humid and sub-humid areas [26-30]. Nowadays, Zebu are widely distributed across different agro-ecological areas of West Africa (Table 1). One analysis [31] has described the following 13 local Zebu cattle breeds in seven countries belonging to the area known as "Centre International de Recherche-Développement de l'Elevage en Zone Subhumide": N'Dama, Kouri, BaouléSomba group, Lagoon cattle group, Azawak Zebu, Maure Zebu, Touareg Zebu, Goudali Zebu, Bororo Zebu, White Fulani Zebu, Djelli Zebu, Fulani Sudanese Zebu and Gobra Zebu (Toronke). All these local breeds serve mainly for beef production but for other purposes as well $[4,5]$. 
Table 1. West African native cattle breeds: geographic distribution, height at withers and body weight.

\begin{tabular}{|c|c|c|c|c|c|c|c|}
\hline Type & Breed & Area/Countries & HWM & HWF & BWM & BWF & References \\
\hline \multirow{7}{*}{ Taurine } & N’Dama & $\begin{array}{l}\text { Guinea, Mali, Senegal, The Gambia, } \\
\text { Côte d'Ivoire, Burkina Faso, Benin }\end{array}$ & 95-120 & $90-115$ & $220-360$ & $180-300$ & {$[15,26,30,32]$} \\
\hline & Baoulé/Lobi & Côte d'Ivoire, Burkina Faso, Ghana & $100-106$ & 90-103 & $160-300$ & $150-240$ & {$[5,26,31,32]$} \\
\hline & Kouri & Niger, Nigeria & $140-180$ & $126-145$ & $500-750$ & $360-450$ & {$[5,26,31,32]$} \\
\hline & Lagunaire & Benin & 89-106 & 85-103 & $180-280$ & $165-262$ & {$[5,26]$} \\
\hline & Somba & Benin, Togo & 89-106 & 85-103 & $150-215$ & $115-185$ & {$[23,31,33]$} \\
\hline & Bourgou & Benin & - & 112.1 & - & - & {$[26,34]$} \\
\hline & Muturu & Nigeria, Benin & 85-95 & $83-93$ & - & - & {$[5,25,35]$} \\
\hline \multirow{6}{*}{ Zebu } & M'Bororo & Burkina Faso, Nigeria, Mali, Benin, Niger & 128.4 & 122.1 & - & - & {$[26,31,36]$} \\
\hline & Azawak & Niger, Mali, Burkina Faso, Benin & $128-135$ & $122-130$ & $350-500$ & $300-410$ & {$[5,26,31]$} \\
\hline & White Fulani & Nigeria, Niger, Mali, Benin, Ghana & $130-152$ & $118-138$ & $425-665$ & $250-380$ & {$[5,31,37]$} \\
\hline & Sudanese Fulani & $\begin{array}{c}\text { Burkina Faso, Bénin, Côte d 'Ivoire, Mali, } \\
\text { Togo }\end{array}$ & $120-138$ & $115-126$ & $280-345$ & $248-300$ & {$[5,26,31,36]$} \\
\hline & Goudali & $\begin{array}{c}\text { Nigeria, Niger, Benin, Burkina Faso, Ghana, } \\
\text { Mali }\end{array}$ & - & 178.2 & - & 388.42 & {$[31,37]$} \\
\hline & Gobra & Senegal, Mali & $130-144$ & $124-140$ & $300-350$ & $250-300$ & {$[5,31,38,39]$} \\
\hline
\end{tabular}

BWF, body weight of adult female; BWM, body weight of adult male; HWF, height at withers of adult female; HWM, height at withers of adult male. 
Indigenous breeds are the foundation for cattle production in this continental region. They are resistant to diseases and drought, can walk long distances and survive on poor pastures, and show good fertility [40]. Farmers exploit these adaptive traits to use the animals for pulling/towing work and for producing milk and meat [5]. Surveys indicate that farmers derive not only these benefits from their cattle, but they also use the animals for ceremonies and for dowries, and for producing fertilizer (manure) and hides [22,30,41,42].

Taurine cattle are found mostly in the tsetse-infested southern Sudano-Guinean area of West Africa, reflecting their tolerance of trypanosomiasis $[43,44]$. Reared in sedentary systems, taurine cattle are used mostly for meat, socio-cultural needs and pulling/towing power, except for N'Dama cattle, which in some regions are also used to produce milk. Zebu cattle, which are kept in pastoral and agropastoral systems, are used more for milk production because of their higher productivity [22,30]. Nevertheless, farmers in various areas rear multiple cattle breeds in mixed herds in order to benefit from their complementarity. For example, Baoulé cattle are sometimes preferred to Zebu because of their greater disease resistance and grazing ability, while Zebu are preferred to Baoulé because of their higher milk yield, larger size and fecundity, faster growth and stronger traction ability $[45,46]$.

\subsection{Genetic Improvement Programs of Local Breeds in West Africa}

The different experiences of breeding programs involving local cattle breeds in West Africa are summarized in Table 2. This list, which is not exhaustive but instead reflects the availability of documentation, includes "closed nucleus", "open nucleus", "dispersed nucleus" and community-based breeding programs originally implemented within the framework of research and development projects. Closed nucleus schemes carry out genetic improvement efforts exclusively at central stations and distribute improved animals to farmers. Open nucleus programs rely on central stations but also bring in promising animals from farmers' herds [47,48]. Dispersed nucleus schemes carry out genetic improvement in herds of elite farmers, from which breeding animals are distributed to other farmers [48]. In community-based breeding programs, farmers keep all breeding animals and the best young animals are selected for breeding in a communal way, with support from experts [49]. This review does not include traditional breeding practices implemented by pastoralist and transhumant herder societies in West Africa. 
Table 2. Six local cattle breeding programs in West Africa.

\begin{tabular}{|c|c|c|c|c|c|c|}
\hline & $N^{\prime}$ Dama in Senegal & $N^{\prime}$ Dama in Mali & $N^{\prime}$ Dama in the Gambia & $\begin{array}{c}\text { Azawak Zebu in Burkina } \\
\text { Faso }\end{array}$ & Fulani Zebu in Burkina Faso & $\begin{array}{l}\text { Baoulé and Baoulé } x \text { Zebu } \\
\text { Crosses in Burkina Faso }\end{array}$ \\
\hline Period & 1972-ongoing & 1975-ongoing & 1994-ongoing & 2000-2015 & 2005-2018 & 2016-ongoing \\
\hline Breeding objectives & $\begin{array}{l}\text { Meat, milk and } \\
\text { trypanotolerance }\end{array}$ & Meat and trypanotolerance & $\begin{array}{l}\text { Meat, milk and } \\
\text { trypanotolerance }\end{array}$ & Milk & $\begin{array}{l}\text { Milk and control of } \\
\text { inbreeding }\end{array}$ & Meat and trypanotolerance \\
\hline Animals selected & Males and females & Males & Males and females & Males & Males and females & Males \\
\hline Selection criteria & $\begin{array}{l}\text { Females: milk performance. } \\
\text { Males: body weight at } 18 \\
\text { months and daily gain from } \\
18-36 \text { months }\end{array}$ & $\begin{array}{c}\text { Coat color, Body weight at } \\
18 \text { months, Daily gain from } \\
18-36 \text { months }\end{array}$ & $\begin{array}{c}\text { Females: milk performance } \\
\text { in the } 100 \text { first days of } \\
\text { lactation. Males: daily gain } \\
\text { from 0-10 months and } \\
15-35 \text { months }\end{array}$ & $\begin{array}{l}\text { Daily gain and libido at } \\
30 \text { months }\end{array}$ & $\begin{array}{l}\text { Females: own maternal line } \\
\text { milk performance. Males: } \\
\text { daily gain and libido at } \\
30 \text { months }\end{array}$ & $\begin{array}{l}\text { Body weight at } 3-5 \text { years, } \\
\text { Daily gain until } 6 \text { months }\end{array}$ \\
\hline Breeding scheme & Open nucleus & Open nucleus & Open nucleus & Dispersed nucleus & Dispersed nucleus & Village breeding \\
\hline Number of tiers & 3 & 3 & 3 & 2 & 2 & 1 \\
\hline Location of nucleus & Public research center & $\begin{array}{l}\text { Public genetic improvement } \\
\text { center }\end{array}$ & Public research center & Breeders' farms & Elite farms in villages & no nucleus \\
\hline Size of nucleus & $\begin{array}{l}200 \text { females } \\
4 \text { males }\end{array}$ & not reported & not reported & not reported & $\begin{array}{l}233 \text { females } \\
28 \text { males }\end{array}$ & not reported \\
\hline Recording site & Station & Station & Station & Station & Farm & Farm \\
\hline Participation of farmers & $\begin{array}{l}\text { Breeding, reproduction, and } \\
\text { dissemination units }\end{array}$ & $\begin{array}{l}\text { Reproduction and } \\
\text { dissemination units }\end{array}$ & $\begin{array}{l}\text { Reproduction and } \\
\text { dissemination units }\end{array}$ & Dissemination unit & $\begin{array}{l}\text { Selection criteria, Selection } \\
\text { based on recorded } \\
\text { performance (selection } \\
\text { committee) }\end{array}$ & $\begin{array}{l}\text { Selection criteria, Selection } \\
\text { based on recorded } \\
\text { performance (selection } \\
\text { committee) }\end{array}$ \\
\hline Stakeholders involved & $\begin{array}{l}\text { NGO, National research } \\
\text { center }\end{array}$ & $\begin{array}{c}\text { NGO, National genetic } \\
\text { improvement center, } \\
\text { Government extension } \\
\text { service }\end{array}$ & $\begin{array}{l}\text { NGO, National research } \\
\text { center }\end{array}$ & $\begin{array}{l}\text { NGO, National genetic } \\
\text { improvement center, } \\
\text { National research institute }\end{array}$ & $\begin{array}{l}\text { NGO, Farmers' organization, } \\
\text { Ministry of livestock resources } \\
\text { and extension services, } \\
\text { Genetic improvement center }\end{array}$ & $\begin{array}{c}\text { National and foreign } \\
\text { partner universities, } \\
\text { National research institute, } \\
\text { Government extension } \\
\text { services }\end{array}$ \\
\hline Breeders' association & Yes & No & Yes & Yes & Yes & Being set up \\
\hline References & [15-18] & [15-18] & {$[12-14,19,20]$} & Project reports [50] & Project reports & {$[21,22]$} \\
\hline
\end{tabular}




\subsubsection{Case 1: N'Dama in Senegal}

Context and breeding objectives: This program was set up in 1972 in Casamance and Kolda, in the southern sub-humid area of Senegal, with funding from the "Fonds Africain de Coopération (FAC)" and the government. The breeding objective was to improve beef performance of N'Dama cattle $[15,17]$, which were selected because of their cultural and socio-economic importance as a form of savings, dowry, insurance and gifts. To involve farmers and their objectives in the program, an Open Nucleus Genetic Improvement System was adopted in 1991. Milk performance and trypanotolerance were included as breeding objectives [17]. However, trypanotolerance was not directly considered in the selection process [15]. Since 2008, the program has been funded by the African Development Bank and the Food and Agriculture Organization (FAO) in the context of the "Projet de Gestion Durable du Bétail Ruminant Endemique (PROGEBE)" (Sustainable Management of Endemic Ruminant Livestock Project). Milk production, beef performance and trypanotolerance have been maintained as primary objectives.

Breeding scheme: Several breeding schemes have been implemented since 1972. The current stage of the program started in 2008 as a 3-tier open nucleus scheme consisting of a selection unit and a reproduction unit consisting mainly of herds of farmers in a cooperative of N'Dama cattle breeders (CASE N'Dama) and a dissemination unit (village herds) [16]. One of the operational objectives has been to keep a breeding unit with 200 females and 4 males with a change in inbreeding rate per generation of $\Delta \mathrm{F}=0.039$. This system allows introduction and performance testing of 12- to 24-month-old bulls from village herds. In contrast to previous schemes, this program has allowed farmers to participate through their cooperative by providing candidates for the breeding unit, managing reproduction units and disseminating improved animals.

Selection process: in the current open nucleus system, two preselection steps are performed before the final selection when bulls are 36 months old. Bulls 6-18 months old are eligible for preselection based on body weight, and bulls weighing more than $150 \mathrm{~kg}$ at 18 months are preselected. Performance of preselected bulls is tested from 18 to 36 months based on daily gain. Originally the selection criteria were meant to include hematocrit values as an indicator of trypanotolerance, but this was never implemented. The breeding program claims indirect selection for trypanotolerance due to the positive correlation $(0.40-0.70)$ between hematocrit and growth. Best linear unbiased prediction (BLUP) indicates genetic gain of $0.43 \mathrm{~kg}$ per year for weight at 36 months, while heritability estimates are 0.07 for birth weight and 0.12 for weight at 36 months.

\subsubsection{Case 2: N’Dama Cattle in Mali}

Context and breeding objectives: genetic improvement of N'Dama cattle started in 1975 with the objective of improving and conserving trypanotolerant $\mathrm{N}^{\prime}$ Dama cattle in their environment, particularly with respect to beef performance. Originally restricted to a government ranch, the system has since been implemented at various locations. Like Case 1, the current form of Case 2 began in 2008 with funding from the African Development Bank and the FAO through PROGEBE [15,17].

Breeding scheme: a closed nucleus breeding system based on mass selection was implemented on the ranch from 1981 to 1986. Feed and budgetary limitations in the ranching system led to a shift toward participatory management involving livestock technical services and farmers. As a result, selected animals on the ranch were transferred to village farms between 1991 and 1993 in order to test their adaptability to village conditions and strengthen farmer participation in the selection process by including their objectives and practices. This dissemination process was based on a contractual system in which farmers had to return the same number and sex of animals to the ranch after 10 years. A selection scheme based on an open village nucleus was established, but the program failed because of financial difficulties. In 2008, PROGEBE implemented a new center based on an open nucleus selection scheme. The animals previously loaned to farmers were used to reconstitute the selection unit at the "Centre de Conservation et de Multiplication du Bétail Ruminant 
Endemique de Médina Diassa (CCMD/BRE)" (Endemic Ruminant Livestock Reproduction Center).

Selection process: animals were selected based on coat color and conformation. Unblemished fawn animals with massive, stocky conformation were preferred. Animals meeting these conditions were selected based on their daily gain between 8 and 18 months, as long as their weight at 18 months exceeded $150 \mathrm{~kg}$. Trypanotolerance was included in the selection process, and low drug absorption was screened as an auxiliary trait.

\subsubsection{Case 3: N’Dama Cattle in the Gambia}

Context and breeding objectives: the program started in 1995 at the International Trypanotolerance Center $[12-14,19,20]$. The aim was to improve the welfare of the livestock owners and their families through better performance and increased livestock productivity (Bosso, 2006). The program was funded by the Bundesministerium für Wirtschaftliche Zusammenarbeit (BMZ) of Germany from 1994 to 1998, by the FAO until 2000, by the European Union through the project "Programme de Concertation de Recherche-Développement de 1'Elevage en Afrique de 1'Ouest (PROCORDEL)" (Livestock Research-Development Concertation Program in West Africa) until 2008, and since then by the African Development Bank and FAO through PROGEBE $[15,17]$. The breeding objectives of increasing meat and milk production without compromising cattle adaptation and resistance to disease were defined in a participatory way with farmers $[19,20,51]$.

Breeding scheme: an open nucleus scheme was adopted involving 3 units and selection units in one area with moderate tsetse fly prevalence (Kenaba) and one area with high tsetse prevalence (Bansang). Favorable conditions at the Kenaba selection unit led to good birth and weaning rates. Trypanotolerance and adaptation were tested in Bansang.

Selection process: since 2008, a complex selection index has been used that includes growth performance of young bulls and their relatives. At Kenaba, calves were selected based on their daily gain from 0 to 12 months. After weaning, selected calves were transferred to Bansang for performance testing, where the best bulls were selected using an index that took into account their daily gain from 15 to 36 months and the milk productivity of their dams [14]. Each year, the 2 best bulls and 55 best females replaced the males and females in the breeding unit. The second-best bulls were sent to reproduction units, while non-selected bulls were sold to butchers. Selection was carried out in a participatory way by staff from the National Agricultural Research System and by farmers. Genetic monitoring using BLUP showed annual genetic gain of $0.40 \mathrm{~kg}$ and heritabilities of 0.48 for body weight at 12 months and 0.28 for weight at 36 months.

\subsubsection{Case 4: Azawak Zebu Cattle in Burkina Faso}

Context and breeding objectives: in the 1990s, programs have been promoted in Burkina Faso to enhance local dairy production (and thereby reduce milk and dairy product imports), exploit the genetic potential of local breeds, increase the consumption of animal proteins by rural populations and increase farmers' income. Between 2000 and 2015, the development project "Projet de Soutien a la Diffusion du Zebu Azawak" (Project to Support the Dissemination of Azawak Zebu) was implemented with funding from the Belgium Technical Cooperation (BTC) to improve local dairy production. Pure Azawak Zebu were introduced and continuously backcrossed with the local Fulani Sudanese Zebu. The final phase (2011-2015) of the 3-phase project was funded by the BKF program of the Luxembourg Development Cooperation and focused on restoration of degraded pastures. The final phase was carried out at 11 sites (communes) in the Sahel region (Dori, Djibo, Yalgo, Gorom-Gorom, Bajni, Taparko, Arbinda, Kelbo, Pobe-Mengao) and central region (Ziniaré and Ouagadougou) of Burkina Faso. The overall project involved 329 farmers and about 2400 animals. Farmers at each site were organized into 11 Azawak Zebu breed associations, which together made up the National Union of Azawak Zebu Breeders (see Supplementary Materials 1). The stated goals of the program were to increase the population of 
Azawak Zebu, establish a participatory genetic improvement strategy, optimize animal management to increase milk and meat production, and improve the skills of farmers.

Breeding scheme: a dispersed nucleus scheme was implemented [48,49]. Pure Azawak Zebu were subjected to within-breed selection, while Azawak and Fulani Sudanese Zebu were subjected to absorption crossbreeding involving Azawak Zebu bulls.

Selection process: pure Azawak Zebu bulls 9-12 months old were recruited for performance testing at a central station that was equipped to perform artificial insemination. Testicle size, chest girth, body weight and libido were recorded, and the bulls were trained for sperm collection. Sperm quality was evaluated. Bulls at 30 months of age were ranked according to a selection index based on daily gain and libido, then selected by a committee including technicians and farmers. The best bulls were selected and reintroduced into herds as sires, while non-selected and crossbred bulls were destocked. From the start of the program until the end of the second phase, the numbers of pure Azawak Zebu increased by $20 \%$; F1 crosses, 364\%; F2 crosses, 500\%; and pure Fulani Zebu, $483 \%$. The increase in number of pure Fulani Zebu reflected the recruitment of females for crossbreeding. Absorption crossbreeding was judged effective because the prevalence of this genotype in herds decreased from $65.8 \%$ in 2004 to $51.8 \%$ in 2007. In addition, F3 crossbreds appeared in the breeding population. Birth weight was significantly smaller $(\mathrm{p}<0.05)$ for pure Fulani Zebu $(18.9 \pm 3.4 \mathrm{~kg})$ than for pure Azawak Zebu $(20.5 \pm 3.4 \mathrm{~kg}), \mathrm{F} 1$ crossbreds $(20.6 \pm 3.7 \mathrm{~kg})$, and F2 crossbreds $(20.9 \pm 2.4 \mathrm{~kg})$. Milk yield during 186 days of lactation was $625 \pm 198 \mathrm{~kg}$ for pure Azawak Zebu, $516 \pm 218 \mathrm{~kg}$ for F1 crosses and $560 \pm 220 \mathrm{~kg}$ for pure Fulani Zebu [50].

\subsubsection{Case 5: Sudanese Fulani Zebu Cattle in Burkina Faso}

Context and breeding objectives: Fulani Sudanese Zebu cattle, the most important breed of Burkina Faso, has traditionally been kept in the Sahel region, and the cattle are well adapted to the harsh environmental conditions there. However, traditional breeding practices appear to have reduced productivity (see Supplementary Materials 2 and 3). Use of bulls for as long as 7-8 years and selection of replacement bulls from among offspring in the same herd are thought to have increased inbreeding levels. In general, cows with low milk yield were not milked but instead returned to reproduction early, resulting in calving intervals of 12-18 months, shorter than the intervals of 18-24 months for cows producing more milk, which also reflects lactation anestrus. Failure to exclude individuals with low milk production led to an increase in offspring from such cows. In response to this situation, a genetic improvement strategy was implemented through the development project "Projet d'Appui au développement du Zebu Peulh au Sahel" (Project to Support the Development of Fulani Zebu in the Sahel), funded by the BTC and implemented by Veterinarians without Borders Belgium in collaboration with "Association Nodde Noto", a local non-governmental organization (NGO). The project began in the province of Oudalan in 2005 and operated until 2018. Its objective was to combine farmers' traditional knowledge with technical selection criteria to set up a breeding program that would control inbreeding and improve the productivity of Fulani Zebu. In particular, the project aimed to increase milk yield per cow per lactation, fertility, and the number of weaned calves per cow per year (see Supplementary Materials 2 and 3). Selection criteria were determined in a participatory manner, and farmers came up with a long list of possible traits. The project team, representatives of the Ministry of Livestock Resources, and farmers ranked the animals and kept the most important ones. For bulls, the preferred traits were milk production of the dam, body size, head and neck profile, large ears, long tail, and good conformation. For females, the preferred traits were milk production, docility, large pelvis, large and well-fixed udder, long and soft teats, belly size and fertility.

Breeding scheme: this project implemented a dispersed nucleus breeding system [48,49]. The selection unit was elite farmers whom the project team had selected because their herds contained top-breeding females with good maternal lines, they employed good husbandry practices and they were willing to adopt the project strategy and follow its rules. Farmers 
in the reproduction unit were selected by farmers' organizations. The project started with 28 farmers in the selection unit and with 233 breeding cows and only 6 bulls that met the project's criteria for good breeding. The project also purchased additional bulls to supply all 28 herds. A performance testing unit was planned for rearing young bull candidates for selection, but this proved technically difficult and unappealing to farmers, who preferred to keep the young candidates in their own herds. In the end, farmers were allowed to keep their young bulls, and local barns were built for periodically testing young candidate performance.

Selection process: a controlled mating system was implemented in the selection unit, involving top females from good maternal lines and selected bulls. Offspring performance was recorded and young bulls were ranked into 4 groups based on an index that took into account growth, size, and sexual activity. The top bulls (group 1) were distributed to the farmers in the breeding unit; group 2 animals, to farmers for reproduction; and group 3 , to farmers who were not part of the breeding program. Group 4 animals were fattened and sold on the market. A selection committee of 3 farmers and 4 representatives from the Ministry of Livestock Resources and other professional organizations oversaw bull selection.

\subsubsection{Case 6: Baoulé Cattle and Baoulé x Zebu Crossbreds in Burkina Faso}

Context and breeding objectives: Baoule cattle, locally called Lobi, are the most important taurine breed in Burkina Faso. Like many West African taurine breeds, the small but trypanotolerant Baoulé in the hot, humid agroclimatic areas of the country is under pressure because of indiscriminate crossbreeding with Zebu. Since 2016, community-based breeding programs have been implemented for local Baoulé cattle and crossbreds in southwestern Burkina Faso [21,22]. These programs were funded by the Austrian Development Agency through the project "Local cattle breeds of Burkina Faso-Characterization and sustainable use" (LoCaBreed) of the Austrian Partnership for Higher Education and Research and Development. One of the goals of this research and development project was to implement sustainable breeding programs to preserve and improve local cattle breeds. Three breeding programs were implemented in three communities, each with a different production system, involving altogether 100 farmers and 2000 animals. One breeding program involved pure Baoulé cattle in a sedentary system and the native community in the commune of BouroumBouroum, another involved crossbreds in a sedentary system and a native community in Loropeni, and the third involved crossbreds in a transhumant system and a migrant community in Kampti. A participatory approach was used to define breeding objectives: farmers were surveyed about their trait preferences and how they ranked their own herd animals [22]. These investigations showed that body size was the most important selection criterion, indicating that farmers were interested in productive traits. As a result, the programs aimed to improve body size by selecting for weight at a given age and daily gain.

Breeding scheme: village breeding schemes were implemented according to the community-based approach [49], which encourages strong participation of farmers at all stages, from design to implementation. The village herd was considered the unit of selection, and only young males were selected.

Selection process: Body weight of young bull candidates was recorded once and again 6 months later. A general linear model (GLM) was used to examine body weight and weight gain over time, accounting for the linear and quadratic effects of age. An index was calculated that equally weighted current, age-corrected body weight and growth during the previous six months. Animals were classified into 3 groups based on this index, and animals that were heavier and/or growing faster for their age were ranked higher. Trypanotolerance was not included in the selection index; faster-growing young bulls were assumed to be more trypanotolerant [21]. To give farmers full participation in selection, selection committees in each locality comprised 3 local men, 2 women and one person younger than 25. Committees were provided with weight and growth data for each of the 3 groups of bulls, then they were asked to choose the best bull from each group and 
to explain their choices. By 2020, 3 rounds of selection involving 200 candidates were performed, leading to the selection of 70 animals that were distributed for breeding.

\section{Discussion}

\subsection{Context, Breeding Objectives and Selection Criteria}

In West Africa, modern efforts at animal genetic improvement began when colonial settlers with intimate knowledge of specialized breed performance carried out crossbreeding with domestic livestock [52]. However, the sustainability of crossbreeding in West Africa was called into question when these projects faltered for lack of funding and the inability of crossbreds to adapt to deteriorating feed quality and to local diseases. As a result, attention shifted away from crossbreeding toward pure breeding in order to exploit the adaptive features of local breeds [52]. Among the breeding programs covered in the present review, the earliest started in the 1970s in Senegal and Mali, and the various programs have involved local Zebu and taurine cattle and have relied on within-breed selection (N’Dama, Fulani Sudanese Zebu, Baoulé), crossbreeding (Baoulé $\times$ Zebu) or breed substitution (Azawak Zebu).

Many livestock improvement programs in developing countries have failed because they did not allow farmers to participate in the setting of breeding objectives [53-55]. Taking into account farmers' knowledge and preferences about breeding goals is essential for breeding programs that target extensive smallholder production, where animals are kept for a variety of purposes [49] and where economic considerations are not necessarily the only criterion, in contrast to conventional market-oriented breeding programs [56]. In traditional systems, defining realistic, feasible and measurable breeding objectives that reflect beneficiaries' various needs is a challenge. The main breeding objectives for the programs in the present review have been meat and milk production as well as trypanotolerance (Table 2). These objectives were set after investigating farmers' trait preferences in a participatory manner at the start of breeding programs involving Fulani Zebu, Baoulé and crossbreds in Burkina Faso or N'Dama cattle in The Gambia [20,22]. In contrast, the objective of improving beef performance in programs involving N'Dama cattle in Mali and Senegal was decided without involving farmers. Nevertheless, the program in Senegal later included milk as a breeding objective based on farmers' interest [17], although this goal may have been less realistic given the breed's low milk performance.

In addition to productive traits, disease resistance was considered in programs involving N'Dama, Baoulé and crossbred cattle in Burkina Faso. However, breeding programs included this trait in different ways. In Mali and Senegal, the emphasis was on coat color, given that coat color may be more or less attractive to tsetse flies and so can influence trypanotolerance [57]. However, a study of Ethiopian cattle has questioned whether coat color or coat pattern influence risk of tsetse infection [58], contrary to popular perception. Indeed, fitness traits associated with disease resistance are difficult to analyze and select for, even in sophisticated breeding systems [59]. In the breeding program in The Gambia, young bull candidates were reared in tsetse-infested areas. In Senegal and in the Burkina programs involving Faso Baoulé and Zebu $\times$ Baoulé crossbreds, selection took into account the positive correlation between growth and disease resistance: young bulls showing good growth performance were assumed to be more trypanotolerant.

Among the various traits preferred by farmers, it is important to focus on a few that represent breeding goals and are heritable and easy to measure [53]. In the breeding programs in Burkina Faso involving Sudanese Fulani and Azawak Zebu, the breeding traits were either too numerous (Azawak Zebu), or they were difficult to measure, such as libido.

Promotion of good breeding practices can help reduce inbreeding, but this may be overambitious for breeding programs in West Africa, where farmers in extensive production systems typically do not record pedigrees. The Fulani Zebu program in Burkina Faso meant to control inbreeding, but the inbreeding level of the population was never analyzed. 
Nevertheless, inbreeding levels of local cattle in certain parts of Burkina Faso have proven to be lower than expected [60].

\subsection{Breeding Schemes and Selection Processes}

This review covered open nucleus, dispersed nucleus, and village breeding programs (Table 2). In the N'Dama cattle programs in Senegal and Mali, practical constraints led systems to evolve from closed to open nucleus. Open nucleus breeding allows animals to flow between the nucleus and local population in both directions, while the closed scheme allows animals to flow only from the nucleus into the population. Nucleus programs can allow accurate recording of performance in developing countries where such recording does not normally occur on farms [61]. However, nucleus programs require adequate infrastructure and technical input to operate sustainably [62]. Many such programs in developing countries have failed for lack of sustainable support and involvement of the community [53-55]. The success of a nucleus program in West Africa involving Djallonke sheep reinforces this point: the program enjoyed strong support from the government and other sources, and the community participated actively [63].

In closed nucleus programs, maintaining and feeding animals in the breeding unit is costly, which led to the failure of such initiatives in Mali and Senegal. Furthermore, farmers in those programs were not willing to bring their best animals to the breeding unit at the central station [48], which was also the case of farmers in the Sudanese Fulani Zebu program in Burkina Faso, who ultimately were allowed to keep the bull candidates in their herds. Dispersed nucleus systems, in contrast, may be less expensive because animals are handled and managed by the farmers themselves. Working with a dispersed nucleus of interested farmers to distribute genetic gain to the village population can make the breeding program more visible to the final beneficiaries [49].

A potential disadvantage of nucleus schemes is that improvement of local breeds in research stations may not be fully transferred to farmers' herds and flocks. This has led many breeding programs to involve farmers and producers in defining breeding goals and selection criteria [52]. This approach was adopted with Baoulé cattle and Baoulé $\times$ Zebu crossbreds in Burkina Faso as a result of shortcomings of previous approaches and successes with community-based breeding programs involving goats and sheep in Eastern and Central Africa [61,64-70]. Indeed, several studies recommend community-based breeding programs for traditional, low-input smallholder farming systems [10,11,48,49,52,54]. In contrast to a conventional top-down strategy, a community-based approach involves farmers in all steps of implementation in order to take into account indigenous knowledge of breeding practices and objectives. Typically, these programs feature a single tier, with no distinction between breeding and production units because all farmers involved are both breeders and producers [70]. In the community-based program involving Baoulé and Baoulé $\times$ Zebu in Burkina Faso, farmers were deeply involved at various stages of implementation. This design exploited the potential of the village herd to provide a large number of breeding candidates and intense selection.

\subsection{Involvement of Stakeholders and Farmers}

The sustainability of efforts to manage animal genetic resources depends largely on the participation of a wide range of stakeholders, public and private [71], including government, research organizations, NGOs, funding institutions and associations of breeders and livestock keepers $[18,48,71,72]$. Research organizations provide scientific support for setting breeding goals, for conducting genetic and economic assessments, and for developing new techniques and technologies. Governments, NGOs, and funding institutions provide financing, subsidies and capacity-building to enable farmers and their associations to manage breeding programs, monitor genetic progress and preserve breeds [18,71]. The six cases in the present review varied in the extent of stakeholder involvement. In the programs involving N'Dama cattle, research institutions were heavily involved in setting breeding objectives, and in conducting genetic assessments with BLUP, which led to adjustments 
in the breeding schemes. In Burkina Faso, the national research institute INERA and the Centre de Multiplication des Animaux Performants (CMAP) ("Center for Reproduction and Dissemination of Improved Animals") were involved in the breeding programs with Azawak and Fulani Zebu cattle, while two universities and one research institute in Burkina Faso collaborated with two universities in Austria to conduct the programs involving Baoulé and Baoulé $\times$ Zebu crossbreds. These institutions helped define breeding objectives and select breeding animals even in the absence of genetic evaluation. Such efforts can contribute directly to building capacity among the next generation of specialists, reflected in the doctoral students who worked on the breeding programs involving N'Dama cattle in The Gambia or involving Baoulé and Baoulé Zebu crossbreds in Burkina Faso.

This collaboration highlights the potential for institutions in developed countries to build capacity in developing countries. Nevertheless, lack of capacity is not the only obstacle. Even though CMAP has the ability to perform artificial insemination, this technology has not been used in any of the cattle breeding programs in Burkina Faso. This highlights the range of non-scientific and non-technical factors that can interfere with the implementation of new strategies and tools of genetic improvement. These factors can include weak management and excessive bureaucratic constraints [72,73].

The success of breeding programs depends on active participation not only of government and other institutional stakeholders, but also of farmers. The breeding programs in the present review involved local farmers to different extents. The N'Dama breeding program in The Gambia and the programs in Burkina Faso involved farmers in the selection of breeding animals. Selection committees in the community-based programs involving Baoulé and Baoulé $\times$ Zebu crossbreds took into consideration various social actors, including women, in livestock activities. Associations of breeders can contribute to self-maintenance and sustainability of breeding programs, but many areas lack such organizations [72]. In most of the breeding programs in the present review, breeders' associations helped identify candidates for selection and helped disseminate selected animals. Developing countries should facilitate and promote the creation of cooperatives, associations, or other community-level organizations of livestock keepers and should grant them appropriate powers to play an important role in managing animal genetic resources [71]. External support from various stakeholders is frequently necessary to initiate breeding programs, but governmental support is necessary to ensure their long-term sustainability [49,71].

\subsection{Access to Market and Funding}

The ultimate objective of any breeding program is to improve farmers' incomes and livelihoods, and several studies in West Africa identified income generation as a key reason for farmers to keep cattle $[22,30,33]$. Unfortunately, we were unable to identify any official reports or research studies that assessed whether the breeding programs in this review had improved beneficiaries' livelihoods, despite the fact that the programs in Mali and Senegal began in the 1970s. Breeding programs in West Africa should take a holistic approach that includes the entire livestock value chain, from production to market. Thus, such programs should tackle the challenges that face farmers who wish to take their cattle to market. For example, many breeders may not go to market because livestock prices are dictated by local traders who may give little consideration to performance [74]. The breeding programs in the present review did not sufficiently emphasize the market. Creating strong linkages between farmers and the market may encourage farmers to adopt new technologies and techniques in veterinary care and nutrition as well as use better germplasm [74]. This could in turn improve breeding programs.

All the breeding programs reviewed here were funded by outside donors and implemented as development or research projects. Consequently, some of these programs ended when the project lifecycle came to a close, such as the programs involving Fulani and Azawak Zebu in Burkina Faso. Similarly, many breeding programs involving goats and sheep in Brazil stopped for lack of resources [72]. Local governments in developing countries often fail to provide financial support to continue successful breeding programs [62,72]. 
Scarce interest from the public sector and inertia of farmers waiting for public support contribute to lack of investment in breeding programs [72]. Genetic improvement programs should be considered long-term investment projects, which require essential input, strong institutional support, and sufficient funding from government to sustain operations [48,74]. Farmers themselves might even help fund breeding programs if they derived sufficient economic benefit from them.

\section{Conclusions}

In this study we reviewed cattle breeding programs in West Africa by focusing on six cases involving local breeds implemented within the last four decades, whose main objectives were increasing meat and milk production as well as disease resistance. Context, breeding objectives, and implementation were analyzed, including breeding scheme, selection process, stakeholders, outcomes, limitations and lessons learned. The main challenge in all cases was definition of clear and realizable breeding objectives, which is usually the case in extensive production systems. Different schemes including open nucleus and dispersed nucleus were applied with various levels of farmers' involvement. Most of these programs were sponsored by external funding through development or research projects, and some programs stopped after the projects' lifespan. Most projects involved several stakeholders such as NGOs, research institutions, universities, farmers' organizations, and genetic improvement centers, but in some cases their role was limited. Our review shows that successful, sustainable cattle breeding programs in West Africa require strong, continuing support from local governments and other stakeholders. In return, such breeding programs con contribute substantially to national economies and farmers' livelihoods by improving genetic resources.

Supplementary Materials: The following are available online at https:/ /www.mdpi.com/2071-105 0/13/4/2125/s1. 1. Capitalization Report of the Project to Support the Dissemination of Azawak Zebu Phase II (French); 2. Report of the 1st workshop of the genetic improvement monitoring committee of the Sudanese Fulani Zebu project on the validation of the breeding animals' selection criteria (French); 3. Report of the 2nd workshop of the genetic improvement monitoring committee of the Sudanese Fulani Zebu project (French).

Author Contributions: Conceptualization: J.S., M.W., O.A.M., A.S., S.O.-K., P.A.B., A.T., G.M. and D.O. Methodology: J.S., M.W. and D.O. Information collection: D.O. Writing: D.O. and J.S. Visualization: J.S., M.W., O.A.M., A.S., S.O.-K., P.A.B., A.T., G.M., D.O., N.K., B.Y., B.Z.-T. and M.S. Review-Editing: J.S., M.W., O.A.M. and A.S. Supervision: J.S., M.W., O.A.M., A.S., S.O.-K., P.A.B., A.T. and G.M. All authors have read and approved the final version of the manuscript for publication.

Funding: This research was funded by the Austrian Development Agency (ADC) through the Austrian Partnership Program in High Education and Research for Development (APPEAR) project 120 (LoCaBreed: Local Cattle Breed of Burkina Faso-Characterization and Sustainable Use).

Institutional Review Board Statement: Not applicable.

Informed Consent Statement: Not applicable.

Acknowledgments: We would like to thank all the authors whose research findings contributed to this review. We are particularly grateful to Bognana Rigobert Taunsi, Konkobo Bernard and Doulkoum Eugène, former employees of the breeding projects involving Azawak and Fulani Zebu in Burkina Faso who provided valuable literature and information.

Conflicts of Interest: The authors declare no conflict of interest.

\section{References}

1. Dessie, T.; Mwai, O. The Story of Cattle in Africa: Why Diversity Matters; International Livestock Research Institute, Rural Administration of the Republic of Korea and the African Union-InterAfrican Bureau for Animal Resources: Nairobie, Kenya, 2019.

2. FAOSTAT FAO Statistical Database. 2019. Available online: http://www.fao.org/faostat/en/ (accessed on 12 August 2020). 
3. Mwai, O.; Hanotte, O.; Kwon, Y.-J.; Cho, S. Africa Indigenous Cattle: Unique Resources in Rapidly Changing World. Asian Australas. J. Anim. Sci. 2015, 28, 911-921. [CrossRef] [PubMed]

4. Rewe, T.O.; Herold, P.; Kahi, A.K.; Zarate, A.V. Breeding indigenous cattle genetic resources for beef production in Sub-Saharan Africa. Agriculture 2009, 38, 317-326. [CrossRef]

5. Rege, J.E.O.; Yapi-Gnaore, C.V.; Tawah, C.L. The indigenous domestic ruminant genetic resources of Africa. In Proceedings of the 2nd All Africa Conference on Animal Agriculture, Pretoria, South Africa, 1-4 April 1996; pp. 57-75.

6. Rege, J.E.O.; Tawah, C.L. The state of African cattle genetic resources II. Geographical distribution, characteristics and uses of present-day breeds and strains. Anim. Genet. Resour. Inf. 1999, 25, 1-25. [CrossRef]

7. DAD-IS FAO's Domestic Animal Diversity Information. 2019. Available online: http://www.fao.org/dad-is/en (accessed on 12 August 2020).

8. Hanotte, O.; Tawah, C.L.; Bradley, D.G.; Okomo, M.; Verjee, Y.; Ochieng, J.; Rege, J.E.O. Geographic distribution and frequency of a taurine Bos taurus and an indicine Bos indicus Y specific allele amongst sub-saharan African cattle breeds. Mol. Ecol. 2009, 9, 387-396. [CrossRef] [PubMed]

9. Gamaniel, I.B.; Egahi, J.O.; Addass, P.A. Effect Year of Calving and Parity on the Productive and Performance of Holstein Friesan Cows in Vom Nigeria. Asian J. Res. Anim. Vet. Sci. 2019, 4, 1-8.

10. Haile, A.; Wurzinger, M.; Mueller, J.; Mirkena, T.; Duguma, G.; Mwai, O.; Sölkner, J.; Rischkowsky, B. Guidelines for Setting up Community-Based Sheep Breeding Programs in Ethiopia; ICARDA-Tools and Guidelines No.1: Aleppo, Syria, 2011.

11. Haile, A.; Wurzinger, M.; Mueller, J.P.; Mirkena, T.; Duguma, G.; Rekik, M.; Mwacharo, J.; Mwai, O.; Sölkner, J.; Rischkowsky, B. Guidelines for Setting Up Community-Based Small Ruminants Breeding Programs in Ethiopia; ICARDA-tools and Guidelines No.1: Beirut, Lebanon, 2018.

12. Bosso, N.A.; Van der Waaij, E.H.; Kahi, A.K.; Van Arendonk, J.A.M. Genetic analysis of N'Dama cattle breed selection schemes. Livest. Res. Rural Dev. 2009, 21, 135.

13. Bosso, N.A. Genetic Improvement of Livestock in Tsetse Infested Area in West Africa. Ph.D. Thesis, Wageningen University, Wageningen, The Netherlands, 2006.

14. Bosso, N.A.; Corr, N.; Nie, M.; Fall, A.; Van der Waaij, E.H.; Van Arendonk, J.A.M. The N'Dama cattle genetic improvement programme: A review. Anim. Genet. Resour. Inf. 2007, 40, 65-69. [CrossRef]

15. Camara, Y. Analyse Sociotechnique et Organisationnelle du Programme de Sélection du Bovin N’Dama au Sénégal. Ph.D. Thesis, Université de Liège, Liège, Belgium, 2019.

16. Camara, Y.; Moula, N.; Sow, F.; Sissoko, M.M.; Antoine-Moussiaux, N. Analysing innovations among cattle smallholders to evaluate the adequacy of breeding programs. Animal 2018, 13, 417-426. [CrossRef]

17. Camara, Y.; Sissoko, M.M.; Sall, M.; Farnir, F.; Antoine-Moussiaux, N. Programme de sélection du bovin N’Dama en Afrique de l'Ouest: Cas du sénégal, du Mali et de la Gambie. Cah. Agric. 2020, 29. [CrossRef]

18. Camara, Y.; Sow, F.; Govoeyi, B.; Sissoko, M.M.; Antoine-Moussiaux, N. Stakeholders involvement in cattle-breeding program in developping countries: A Delphi survey. Livest. Sci. 2019, 228, 127-135. [CrossRef]

19. Dempfle, L.; Jaitner, J. Case study about the N'Dama breeding programme at the International Trypanotolerance Centre (ITC) in the Gambia. In ICAR Technical Series No. 3; The International Committee for Animal Recording: Rome, Italy, 2000.

20. Jaitner, J.; Corr, N.; Dempfle, L. Ownership pattern and management practices of cattle herds in The Gambia: Implication for a breeding programme. Trop. Anim. Health Prod. 2003, 35, 179-187. [CrossRef]

21. Ouédraogo, D.; Soudré, A.; Oudéraogo-Koné, S.; Yougbaré, B.; Zoma, B.L.; Tapsoba, S.A.R.; Mészáros, G.; Burger, P.; Khayatzadeh, N.; Wurzinger, M.; et al. Selection of breeding bulls in community-based cattle breeding programs in Burkina Faso. Bull. Anim. Health Prod. Afr. 2020, 68, 103-111.

22. Ouédraogo, D.; Soudré, A.; Ouédraogo-Koné, S.; Zoma, B.L.; Yougbaré, B.; Khayatzadeh, N.; Burger, P.A.; Mészáros, G.; Traoré, A.; Mwai, A.O.; et al. Breeding objectives and practices in three local cattle breed production systems in Burkina Faso with implication for the design of breeding programs. Livest. Sci. 2020, 232, 103910. [CrossRef]

23. Rege, J.R.O. Shorton Cattle of West and Central Africa. IV. Productions Characteristics. World Anim. Rev. 1994, $78,33-43$.

24. Kim, K.; Kwon, T.; Dessie, T.; Yoo, D.; Mwai, A.O.; Jang, J.; Sung, S.; Lee, S.; Salim, B.; Jung, J.; et al. The mosaic genome of indigenous African cattle as a unique genetic resource for African pastoralism. Nat. Genet. 2020, 52, 1099-1110. [CrossRef]

25. Blench, R. Traditional Livestovk Breeds: Geographical Distribution and Dynamics in Relation to the Ecology of West Africa; Overseas Development Institute: London, UK, 1999; p. 69.

26. Traoré, A.; Koudandé, D.O.; Fernandez, I.; Soudré, A.; Granda, V.; Alvarez, I.; Diarra, S.; Diarra, F.; Kaboré, A.; Sanou, M.; et al. Geographical assessment of body measurements and qualitative traits in West African cattle. Trop. Anim. Health Prod. 2015, 47, 1505-1513. [CrossRef] [PubMed]

27. Jabbar, M.A.; Swallow, B.M.; D'Ieteren, G.D.M.; Busari, A.A. Farmer preferences and market values of cattle breeds of West and Central Africa. J. Sustain. Agric. 1998, 12, 21-47. [CrossRef]

28. Kamuanga, M.; Tano, K.; Pokou, K.; Jabbar, M.A.; Swallow, B.; D'ieteren, G. Faremres' preferences of cattle breeds, their market values and prospects for improvement in West Africa: A summary review. In Proceedings of the 25th Meeting of the International Scientific Council for Trypanosomiasis Research and Control (ISCTRC), Mombasa, Kenya, 27 September-2 October 1999; pp. 271-298.

29. Boutrais, J. The Fulani and cattle breeds: Crossbreeding and heritages strategies. Africa 2007, 77, 18-36. [CrossRef] 
30. Traoré, S.A.; Markemann, A.; Reiber, C.; Piepho, H.P.; Valle Zarate, A. Production objectives, traits and breeds preferences of farmers keeping N'Dama, Fulani Zebu and crossbreed cattle and implication for breeding programs. Animal 2017, 11, 687-695. [CrossRef] [PubMed]

31. Belemsaga, D.M.A.; Lombo, Y.; Thevenon, S.; Sylla, S. Inventory analysis of West African cattle breeds. In Applications of Gene-Based Technologies for Improving Animal Production and Health in Developing Countries; Springer: Dordrecht, The Netherlands, 2005; pp. 167-173. [CrossRef]

32. Gréma, M.; Traoré, A.; Issa, M.; Hamani, M.; Abdou, M.; Fernandez, I.; Soudré, A.; Alvarez, I.; Sanou, M.; Tamboura, H.H.; et al. Morphological assessment of Niger Kuri cattle using multivariate methods. South Afr. J. Anim. Sci. 2017, 47, 505-515. [CrossRef]

33. Dossa, L.H.; Vanvanhossou, F.U.S. The indigenous Somba cattle of the hilly Atacora region in North-West Benin: Threatsand opportunities for its sustainable use. Trop. Anim. Health Prod. 2016, 48, 349-359. [CrossRef] [PubMed]

34. Alkoiret, I.T.; Yari, H.M.; Gbangboche, A.B.; Lokossou, R. Reproductive Performance and Milk Production of Girolando Cows in the Ranch of Kpinnou, South-West of Benin Republic. J. Anim. Vet. Adv. 2011, 10, 2588-2592.

35. Tijjani, A.; Utsunomiya, T.Y.; Ezkwe, G.A.; Nashiru, O.; Hanotte, O. Genome Sequence Analysis Reveals Selection Signatures in Endangered Trypanotolerant West Africa Muturu Cattle. Front. Genet. 2019, 10. [CrossRef] [PubMed]

36. Moussa, M.M.A.; Issa, M.; Traoré, A.; Gréma, M.; Hamani, M.; Fernandez, I.; Soudré, A.; Alvarez, I.; Sanou, M.; Tamboura, H.H.; et al. Morphological assessment of the Zebu Bororo (Wodaabé) cattle of Niger in the West African zebu framework. Arch. Anim. Breed 2017, 60, 363-371. [CrossRef]

37. Umar, D.S.B.; Nwagu, B.I.; Umar, U.A.; Rufina, O.O.; Saleh, I.; Onotu, S.I.; Ugwu, L. On-station Performance Evaluation of Indigenous Breeds of Cattle for Dairy Production Systems in Nigeria. Asian J. Res. Agric. For. 2020, 5, 30-38. [CrossRef]

38. Marshall, K.; Tebug, S.; Salmon, G.R.; Tapio, M.; Juga, J.; Missou, A. Improving dairy cattle productivity in Senegal. ILRI Policy Brief: Nairobie, Kenya. 2017, 22.

39. Ngono, E.P.J.; Lassila, L.; Missohou, A.; Marshall, K.; Tapio, M.; Tebug, S.F.; Juga, J. Milk production traits among indigenous and crossbred dairy cattle in Senegal. Afr. J. Food Agric. Nutr. Dev. 2018, 18, 13572-13587.

40. Ahozonlin, C.M.; Koura, B.I.; Dossa, L.H. Determinants of Crossbreeding Practices by Cattle Farmers in South Benin, West Africa: Implications for the Sustainable Use of the Indigenous Lagune Cattle Population. Sustain. Agric. Res. 2019, 8, 101-109. [CrossRef]

41. Ejlertsen, M.; Poole, J.; Marshall, K. Traditional breeding objectives and practices of goat, sheep and cattle smallholders in The Gambia and implications in relation to the design of breeding interventions. Trop. Anim. Health Prod. 2013, 45, 219-229. [CrossRef] [PubMed]

42. Yakubu, A.; Dahloum, L.; Gimba, E.G. Smallholder cattle farmers' breeding practices and trait preferences in a tropical Guinea savanna agro-ecological zone. Trop. Anim. Health Prod. 2019, 51, 1497-1506. [CrossRef]

43. Soudré, A.; Ouédraogo-Koné, S.; Wurzinger, M.; Müller, S.; Hanotte, O.; Ouédraogo, A.G.; Sölkner, J. Trypanosomosis: A priority disease in tsetse-challenged areas of Burkina Faso. Trop. Anim. Health Prod. 2013, 45, 497-503. [CrossRef]

44. Silbermayr, K.; Li, F.; Soudré, A.; Müller, S.; Sölkner, J. A Novel qPCR Assay for the Detection of African Animal Trypanosomosis in Trypanotolerant and Trypanosusceptible Cattle Breeds. PLoS Negl. Trop. Dis. 2013, 7, e2345. [CrossRef] [PubMed]

45. Tano, K. Genetic Preferences of Smallholders and Trypanotolerant Cattle in Southern Burkina Faso. Ph.D. Thesis, Univesity of Manitoba, Winnipeg, MB, Canada, 1998.

46. Tano, K.; Kamuanga, M.; Faminow, M.D.; Swallow, B. Using conjoint analysis to estimate farmer's preferences for cattle traits in West Africa. Ecol. Econ. 2003, 45, 393-407. [CrossRef]

47. Gicheha, M.G.; Kosgey, I.S.; Bebe, B.O.; Kahi, A.K. Evaluation of the efficiency of alternative two-tier nucleus breeding systems designed to improve meat sheep in Kenya. J. Anim. Breed. Genet. 2006, 123, 247-257. [CrossRef] [PubMed]

48. Kahi, A.K.; Rewe, T.O.; Kosgey, I.S. Sustainable communitybased organizations for the genetic improvement of livestock in developing countries. Outlook Agric. 2005, 34, 261-270. [CrossRef]

49. Mueller, J.P.; Rischkowsky, B.; Haile, A.; Philipsson, J.; Mwai, O.; Besbes, B.; Valle Zarate, A.; Tibbo, M.; Mirkena, T.; Duguma, G.; et al. Community-based livestock breeding programs: Essentials and examples. J. Anim. Breed. Genet. 2015, 132, 155-168. [CrossRef]

50. Tamboura, H.H.; Gnanda, B.I.; Kaboré, A.; Traoré, A. Bilan Des Acquis du Programme D'amélioration Génétique Mis en Place Dans le Cadre du Projet de Soutien à la Diffusion du Zébu Azawak (PSDZA) Phase II; INERA: Ouagadougou, Burkina Faso, 2008 ; p. 61.

51. Steglich, M.; Peters, K.J. Agro-pastoralists' trait preference in N'Dama cattle: Participatory methods to assess breeding objectives. In Proceedings of the 7th World Congress on Genetics Applied to Livestock Production, Montpellier, France, 19-23 August 2002.

52. Madalena, F.E.; Agyemang, K.; Cardellino, R.C.; Jain, G.L. Genetic improvement in medium-to low-input systems of animal production. In Proceedings of the 7th World Congress on Genetics Applied to Livestock Production, Montpellier, France, 19-23 August 2002.

53. Sölkner, J.; Nakimbugwe, H.; Valle Zarate, A. Analysis of Determinants for Success and Failure of Village Breeding Programmes In Proceedings of the 6th Congress on Genetics Applied to Livestock Production, Armidale, NSW, Australia; 1998; Volume 25, pp. 273-280.

54. Sölkner, J.; Grausgruber, H.; Okeyo, A.M.; Ruckenbauer, P.; Wurzinger, M. Breeding objectives and the relative importance of traits in plant and animal breeding: A comparative review. Euphytica 2008, 161, 273-282. [CrossRef]

55. Wurzinger, M.; Sölkner, J.; Iniguez, L. Important aspects and limitations in considering community-based breeding programs for low-input smallholder livestock systems. Small Rumin. Res. 2011, 98, 170-175. [CrossRef] 
56. Goddard, M.E. Consensus and debate in the definition of breeding objectives. J. Dairy Sci. 1998, 81, 6-18. [CrossRef]

57. Stein, J. Trypanotolerance and Phenotypic Characteristics of Four Ethiopian Cattle Breeds. Ph.D. Thesis, Swedish University of Agriculture Sciences, Uppsala, Sweden, 2011.

58. Stein, J.; Ayalew, W.; Rege, E.; Mulatou, W.; Lemecha, H.; Tadesse, Y.; Tekle, T.; Philipsson, J. Trypanosomosis and phenotypicfeatures of four indigenous cattle breeds in an Ethipian field study. Vet. Parasitol. 2011, 178, 40-47. [CrossRef] [PubMed]

59. Heringstad, B.; Klemetsdal, G.; Ruane, J. Selection for mastitis resistance in dairy cattle: A review with focus on the sistuation in the Nordic countries. Livest. Prod. Sci. 2000, 64, 95-106. [CrossRef]

60. Ouédraogo, D.; Oudéraogo-Koné, S.; Yougbaré, B.; Soudré, A.; Zoma-Traoré, B.; Mészáros, G.; Khayatzadeh, N.; Traoré, A.; Sanou, M.; Mwai, A.O.; et al. Population structure, inbreeding and admixture in local cattle populations managed by community-based breeding programs in Burkina Faso. J. Anim. Breed. Genet. 2020. (Paper in Production).

61. Guangul, A.S. Design of Community-Based Breeding Programs for Two Idigenous Goats Breed in Ethiopia. Ph.D. Thesis, University of Natural Resources and Life Sciences, Vienna, Austria, 2014.

62. Kosgey, I.S.; Baker, R.L.; Udo, H.M.J.; van Arendonk, J.A.M. Successes and failures of small ruminant breeding programmes in the tropics: A review. Small Rumin. Res. 2006, 61, 13-28. [CrossRef]

63. Yapi-Gnaoré, C.V. The open nucleus breeding programme of the Djallonke sheep in Côte D'Ivoire. In Proceedings of the Workshop on Developing Breeding Strategies for Lower Input Animal 712 Production Environments, Bella, Italy, 22-25 September 1999.

64. Duguma, G.; Mirkena, T.; Haile, A.; Okeyo, A.M.; Tibbo, M.; Rischkowsky, B.; Sölkner, J.; Wurzinger, M. Identification of smallholder farmers and pastoralists' preferences for sheep breeding traits: Choice model approach. Anim. Int. J. Anim. Biosci. 2011, 5, 1984-1992. [CrossRef]

65. Mirkena, T.; Duguma, G.; Willam, A.; Wurzinger, M.; Haile, A.; Rischkowsky, B.; Okeyo, A.M.; Tibbo, M.; Sölkner, J. Communitybased alternative breeding plans for indigenous sheep breeds in four agro-ecological zones of Ethiopia. J. Anim. Breed. Genet. 2012, 129, 244-253. [CrossRef]

66. Mirkena, T. Identifying Breeding Objectives of Smallholders/Pastoralists and Optimizing Community-Based Breeding Programs for Adapted Sheep Breeds in Ethiopia. Ph.D. Thesis, University of Natural Resources and Life Sciences, Vienna, Austria, 2010.

67. Duguma, G. Participatory Definition of Breeding Objectives and Implementation of Community-Based Sheep Breeding Programs in Ethiopia. Ph.D. Thesis, University of Natural Resources and Life Sciences, Vienna, Austria, 2010.

68. Nandolo, W.; Wurzinger, M.; Gabor, M.; Van Tassell, C.; Gondwe, T.; Mulindwa, H.; Lamuno, D.; Sölkner, J. Identification of breeding objectives in community based goat breeding programmes in Malawi 2016. Acta Agric. Slov. 2016, 5, 104.

69. Kaumbata, W.; Banda, L.; Mészáros, G.; Gondwe, T.; Woodward-Greene, M.J.; Rosen, D.B.; Van Tassell, P.C.; Sölkner, J.; Wurzinger, M. Tangible and intangible benefits of local goats rearing in smallholders farms in Malawi. Small Rumin. Res. 2020, 187, 106095. [CrossRef]

70. Gizaw, S.; Abebe, A.; Bisrat, A.; Zewdie, T.; Tegegne, A. Defining smallholders' sheep breeding objectives using farmers trait preferences versus bio-economic modelling. Livest. Sci. 2018, 214, 120-128. [CrossRef]

71. Leroy, G.; Baumung, R.; Notter, D.; Verrier, E.; Wurzinger, M.; Scherf, B. Stakeholder involvement and the management of animal genetic resources across the world. Livest. Sci. 2017, 198, 120-128. [CrossRef]

72. Lobo, R.N.B. Opportunities for investment into small ruminant breeding programmes in Brazil. J. Anim. Breed. Genet. 2019, 136, 313-318. [CrossRef]

73. Ducrocq, V.; Laloe, D.; Swaminathan, M.; Rognon, X.; Tixier-Boichard, M.; Zerjal, T. Genomics for Ruminants in Developing Countries: From Principles to Practices. Front. Genet. 2018, 9, 251. [CrossRef] [PubMed]

74. Gowane, G.R.; Kumar, A.; Nimbkar, C. Challenges and opportunities to livestock breeding programmes in India. J. Anim. Breed. Genet. 2019, 136, 329-338. [CrossRef] [PubMed] 